\title{
The Syndrome of FDI and Economic Growth: Evidence from Latin American Countries
}

\author{
Husam Rjoub, Ahmad Abu Alrub, Kemal Soyer and Sameer Hamdan
}

Cyprus International University, Haspolat, North Cyprus

Correspondence should be addressed to: Ahmad Abu Alrub; aalrub@ciu.edu.tr

Received date: 3 March 2015; Accepted date: 29 June 2015; published date: 27 June 2016

Copyright (C) 2016. Husam Rjoub, Ahmad Abu Alrub, Kemal Soyer and Sameer Hamdan. Distributed under Creative Commons CC-BY 4.0

\begin{abstract}
The study investigated the impacts of FDI inflow on the economic growth of Latin American countries for the period 1995 to 2013 by using a panel data model. The countries peculiar characteristics of domestic investment percent of GDP, openness of trade percent of GDP, inflation, human capital, and government expenditure percent of GDP were used to achieve the study objective. Results showed that the current economic growth in the selected Latin American countries was positively affected by the FDI inflow. While findings showed a negative relationship between human capitals and economic growth, they showed a significant relationship between domestic investment and economic growth which suggested that FDI has no crowding out effect on the current domestic investment. In the study attempt to add to the existing knowledge on FDI-led growth, it initiated the research on exploring the seven largest recipients of FDI inflows among Latin American countries. It also attempted to clarify the role human capital endowment played in FDI attraction during the specified period.
\end{abstract}

Key words - foreign direct investment (FDI), human capital, economic growth, Latin America

\section{Introduction}

Historically, it is beyond every reasonable doubt that, FDI has had two strands in terms of its contributions to development and especially how it shapes the productive sector in Latin America, such that it has gained massive attention in the economic literature. This presumes that FDI is seen as a key driver of a global economic integration which has the ability to provide financial stability, promote economic development as well as enhance the well-being of the society
(OECD, 2008), as Adams (2009) asserted that, for the past couple of years the inflows of such investments into the developing economies in Latin America, and the SSA have experienced a commensurable increase. Despite the overwhelming consensus on the contributions of FDI inflows in the economic development, the debate on its (FDI) impact on local development has been full of loopholes because of how cumbersome it is to analytically isolate the prevailing business and institutional conditions, such as the host nations' technological and human

Cite this Article as: Husam Rjoub, Ahmad Abu Alrub, Kemal Soyer and Sameer Hamdan (2016), "The Syndrome of FDI and Economic Growth: Evidence from Latin American Countries”, Journal of Financial Studies \& Research, Vol. 2016 (2016), Article ID 542185, DOI: 10.5171/2016.542185 
capabilities, and their respective regulatory frameworks, among other factors.

In as much as it is evidently clear that there is a link between FDI inflows and the host nations' peculiar characteristics, it therefore becomes a fundamental obligation for policy makers over the world to develop unique measures to attract FDI into their respective economies as in the last couple of decades throughout Latin America, governments or policy makers have readjusted tariffs and subsidies; barriers of foreign investments and other governmental factors under the jurisdiction of the state authorities or policy makers (Lora, 2001). It could therefore be assumed that FDI is desirable particularly for the developing countries (Yusufu, 2013) of which Latin American countries are of no exception. Notwithstanding, a considerable number of literature is still doubtful with its (FDI Inflows) ability to lead to the economic growth of the host countries, as attracting FDI alone does not represent a complete panacea for generating economic growth but rather needs to be backed with comprehensive development strategies and policies that will foster the intended FDI-led growth.

These and other inseparable factors have been the subject for numerous studies both theoretical and empirical (Borensztein et al, 1998; Alfaro, 2003; Anyanwu, 2014) to explore the impact of FDI-led growth of the host economies where in most cases countries in Latin America and SSA receive much attention forgetting the fact that, drawing conclusions based on collective results or facts is sometimes deceptive since their individual impact would be suppressed by the dominant ones.

To have a clearer idea of how FDI affects individual countries, this paper seeks to investigate the impact of FDI on the economic growth of selected countries from Latin ${ }^{1}$ America The major contribution of our study on FDI-led growth to the existing literature would be the inclusion of human capital to the sample countries in Latin America with similar economic and social characteristics (largest FDI receiver). The remainder of the study is subsequently organized as follows: the next immediate section evokes a related literature review of both theoretical and empirical evidence of FDI on economic growth; methodology used for the study, followed by a discussion of the empirical results and findings, and finally ends with concluding remarks and policy implications.

\section{Literature review}

The impact of FDI on economic growth still remains doubtful despite the fact that different theoretical explanations exist on how FDI can influence the economic growth (Yusufu, 2013). As some studies emphasized financial development (Alfaro et al, 2013; Alfaro et al, 2004) others point to human capital (Borensztein et al, 1998). Adding to the ongoing discussion of this challenge, Yusufu (2013) was of two views, the first according to him was the essence of FDI to the developing countries and emphasized the various factors that increase their inflow and the question of whether FDI leads to growth and development in the recipient country.

De Mello (1999) was also with the view that FDI has a positive direct and indirect impact on economic growth especially in developing countries but contended that such effects can be isolated from the roles the host country's factors play in facilitating growth since the FDI itself does not necessarily lead to growth (Yusufu, 2013). Following the neoclassical and endogenous growth theory, FDI respectively increases the stock of physical capital in the recipient economy and therefore directly affects economic growth as well as encouraging human capital development, and brings about technological advancement and affects economic growth indirectly (De Mello 1999).

A number of squabbles have been surrounding FDI-Led Growth effect despite the positive impacts of its (FDI) inflows on the growth of the host countries' economies. For instance, considering the dependency theory, Bornschier and Chase-Dunn (1985) noted that FDI leads to inefficient market structures like monopoly. And also paves the way for a disarticulated growth pattern in 
economies or industries highly dominated by foreign firms (Amin, 1974).

Taking into consideration the factors like the host country characteristics or the assumptions on which growth models were built, it therefore becomes clearer how FDI affects the growths of those countries concerned. Even though De Mello (1999) asserted that FDI inflows affect growth only in the short term, taking into account the diminishing returns of capital in the neoclassical growth model of Solow (1956). Further considering FDI impacts, Romer $(1986,1990)$ and the economists of endogenous growth came out with another framework to aid the FDI impact analyses on growth by postulating that the returns of capital are no more diminishing but they are constant over time as supported by De Mello (1999) who was also with the view that FDI has a positive impact on the long-run growth contrary to the short term effects of FDI inflows on economies as noted by De Mello (1999). In addition to the stands of these theorists, they (endogenous growth theorists) further postulated that technical progress, knowledge, and human capital are endogenous determinants of growth and may explain its snowballing aspect. As De Mello (1999) and Mehic et al. (2013) argued that FDI endorses technological and knowledge spill over that in turn lead to growth which depends on the extent to which it complements or substitutes domestic investment. As clearly envisaged from the aforementioned discussion, taking into consideration the host countries' characteristics, the impact of FDI on growth surely depends on factors like sound institutional environment, natural resources endowment, and telecommunication infrastructures.

Widespread research has previously focused on the economic development of developing countries from numerous perspectives. The impact of FDI inflows on economic enhancement attracted much attention and studies indicate that FDI plays a crucial role in the growth of the receiving country due to additional tax revenue from international investors (Quazi, 2007). Since international trade has doubled, FDI flows have gained much popularity all around the globe. Nonetheless, mutually macro and micro empirical verification seems to be complicated. While some studies suggest advantageous and negative effects on growth, others find no effect on economic growth at all (Görg and Greenaway 2004). The unconvincing empirical research led some researchers to generalize conclusions regarding the external factors linked to FDI (assuming positive spill-overs could trigger inappropriate policy decisions) (Alguacil et al., 2011).

Egan, (2010) confirms that FDI has been agreed to be a major provider of growth by transporting capital, technology, management know-how skills, jobs, and prosperity to the recipient economy. Up to date, research on FDI inflows in Latin America proposes that even though FDI has a number of optimistic effects on economic growth, the benefits are not accumulated equally or uniformly across countries and economies. One recent study of Blanco (2012) considers the significance of natural resource dependence as a determinant of capital inflows in Latin America and further analyses 17 countries from 1986 to 2006 . On the one hand, the author finds out that population is significant for development and the governance variable is positively significant according to statistics. On the other hand, the study discovers democracy and internal stability as positive, however not statistically significant. Finally, corruption and surrounding market potential was statistically significant.

In a different cross-sectional study which included 37 countries from Africa, Asia and Latin America from 1990 to 2007, Neelankavil et al, (2011) investigated the factors that have an impact on real GDP in the long-run and also the short-run. Have FDI inflows to developing countries really caused growth? The study finds that whilst growth in real FDI does influence growth in real GDP for these developing countries but only in the short-run and not very essential with explaining growth in the long-run. As a result of their findings, they suggest trade, 
monetary and fiscal policy, and human capital investment are more significant in the long-run. They also found that real government expenditures were significant according to statistics and held a relationship with GDP. Additionally, the authors reveal that higher productivity depends on the minimum threshold stock of human capital and technology transfer from advanced economies to developing ones contributing to growth (Neelankavil et al., 2011). Kottaridi and Stengos (2010) also confirm the significant impact of human capital on growth in their all-embracing analysis.

Moreover, focusing on 18 Latin American countries, Bengoa and Sanchez-Robles (2003) attempted to discover the relationship amongst economic freedom, FDI and economic growth utilising panel data between the years of 1970 and 1999. They explored that FDI is positively correlated with economic growth in the recipient countries. Nevertheless, the hosting country needs sufficient human capital, economic stability and market liberalization to benefit from long-term capital flows (Bengoa and Sanchez-Robles, 2003). Furthermore, Alguacil et al., (2011) carried out a nonoverlapping 5-year periods analysis from 1976 to 2005 involving 26 developing countries using a regression model on a dynamic. When introducing the inflation rate variable, FDI ceased to have a significant effect on growth, however, FDI was found to be at all times significant. One other research by Naveed and Shabbir (2006), they examined the impact of FDI and trade openness on per capita GDP growth from 1971-2000 on developed countries and discovered that openness was significant and positively affecting growth.

In contrary, some researchers such as Carkovic and Levine (2005) examined the impact of FDI on growth in 72 economies during the period between 1960 and 1995, and explored that FDI does not influence growth. In addition to the contrasting views and results obtained by panel data covering several countries, Kottaridi and Stengos (2010) carried out an extensive empirical analysis of numerous studies including some of the previously mentioned authors. They cite De Gregorio (1992) who analysed 12 Latin-American economies using the panel data technique starting from 1950 to 1985 and found that there is positive and significant correlation amongst FDI and development.

Moreover, Balasubramanyam et al. (1999) explored from their study that FDI increases development only in economies that apply outward oriented policies. In a different study, Borenztein et al. (1998) discovered FDI increases growth by enabling technological transmission, however, $\mathrm{Xu}$ (2000) discovered this differs from developed to lesser developed countries after using US FDI to 20 developed and 20 lesser developed countries. The author suggests technology transmissions from FDI enhance productivity in developed but not lesser developed economies due to insufficient capital.

\section{Econometric Methodology:}

In order to investigate the effect of Foreign Direct Investment (FDI) on the GDP growth for the "Seven (7) Latin American Countries", the present research is conducted using panel data analysis over a long period of time in across these countries. Panel data analysis is a powerful research technique that can be used to measure the effect of any variables of interest on GDP growth over a period of time and across countries. After verifying the Heterogeneity of panel time series, the expressed model is as follows:

$$
G D P g_{i t}=\beta_{0}+\beta_{1} \log F I_{\mathrm{it}-1}+\beta_{2} \operatorname{ligit-1}_{\text {git }}+\beta_{2} \log (O P E N g)_{\text {it }}+\beta_{4} I N F_{i t}-\beta_{5} H C_{i t}+\beta_{6} G E g_{\text {git }-1}+\varepsilon_{i t}
$$

The data set of this research consists of 126 observations made from the sample (seven) countries (number of country $i$ ) over the period of 1995 to 2013, ( $t$ time period).
Where, GDPg: GDP growth, FDI: foreign direct investment, DIg: Domestic investment percent of GDP, OPENg: openness of trade percent of GDP, INF: inflation rate (consumer 
price index), HC: Human Capital (Secondary school enrolment as a proxy), and GEg: Government Expenditure percent of GDP. $\Sigma_{i t}$
Is the random error. Hausman test is used to compare fixed effect versus random effect panel.

Table 1: The GDP Growth Estimation Results, Panel with Fixed Effect

\begin{tabular}{|c|c|c|}
\hline Variables & Coefficient & \\
\hline Intercept & -28.82717 & $\begin{array}{l}-3.728062 \text { *** } \\
(7.732483)\end{array}$ \\
\hline $\log (F D D)_{i t-1}$ & 1.246310 & $\begin{array}{l}2.522397^{* * *} \\
(0.494097)\end{array}$ \\
\hline$D \lg _{\mathrm{it}-1}$ & 0.380797 & $\begin{array}{l}3.301717^{* * *} \\
(0.115333) \\
\end{array}$ \\
\hline $\log (O P E N g)_{\mathrm{it}}$ & 5.585018 & $\begin{array}{l}3.671152^{* * *} \\
(1.521326)\end{array}$ \\
\hline$I N F_{\mathrm{it}}$ & 0.132880 & $\begin{array}{l}2.561452^{* * *} \\
(0.051877)\end{array}$ \\
\hline$H C_{\text {it }}$ & -0.141998 & $\begin{array}{l}-2.88927^{* *} \\
(0.059440) \\
\end{array}$ \\
\hline$G E g_{i t-1}$ & 0.234879 & $\begin{array}{l}1.974974^{*} \\
(0.118927) \\
\end{array}$ \\
\hline R-squared & 0.525543 & \\
\hline Adjusted R-squared & 0.475158 & \\
\hline Hausman test Random Effect & $\begin{array}{l}x^{2}=23.700846 \\
\text { P-value0.0006** }\end{array}$ & \\
\hline Total panel observation & 126 & \\
\hline \multicolumn{3}{|l|}{ Diagnostic test } \\
\hline Autocorrelation: Baltagi LM-test & \multicolumn{2}{|l|}{$\begin{array}{l}x^{2}=1.878090 \\
\text { P-value } 0.170551\end{array}$} \\
\hline Heteroskedasticity: Erlat LM-test & \multicolumn{2}{|l|}{$\begin{array}{l}x^{2}=3.231918 \\
\text { P-value } 0.13005\end{array}$} \\
\hline
\end{tabular}

$*, * *$ and ${ }^{* * *}$ denotes significant level at $10 \%, 5 \%$ and $1 \%$ respectively. Based on t-statistic, Standard errors are in parentheses. Note: the Null hypotheses of residuals tests are that the residuals don't display any Serial correlation, and are homoscedastic.

\section{Empirical Results}

First of all, the Hausman test emphasizes the rejection of random effect in favour of fixed effect panel model. The accumulated comparative analytical tests for serial correlation and heteroskedasticity signify that the residuals do not reveal any serial correlation and they are homoscedastic.

After an extensive literature review and empirical assessment, visible in the above model, results indicated that lagged FDI affects the current economic growth in Latin American countries. This result is in line with Bengoa and Sanchez-Robles (2003) and Eagen (2010) where both agreed that FDI is key for economic development. Moreover, the results showed that domestic investment is positively and significantly correlated with economic growth during the 17 year panel analysis. The positive impact of domestic investment on economic growth confirms that FDI has no crowding out effect on the current domestic investment. These findings are in line with Mehic et al, 2013 argument 
that the impact of FDI on economic growth depends on the extent to which it complements or substitutes domestic investment.

Furthermore, trade openness has a strong positive and significant effect on economic growth. This is in harmony with Naveed and Shabbir (2006) and Neelankavil et al., (2011) who stressed the importance of trade openness. In other words, Liberalization and being open to trade could be the key for growth for many countries in this globalized era of the free economic market. Lora (2001) confirms in the beginning of 1980s that almost all Latin American countries began programs to lift controls on the trade regimes and tariffs accordingly dropped vastly in the following decade. Inflation was found to be positively and statistically significant for the GDP growth amongst these analysed Latin American countries. This result confirms Muhammad et al (2011) as they also found inflation rate to be positive and significant. On the other hand, the government expenditure variable reveals a different impact on growth than other variables. Our results revealed that government expenditure also has a positive impact on economic development GDP which also confirms Dutta and Roy (2011) and Neelankavil et al., (2011).

Finally, an interesting result is revealed on human capital due to the fact that it is negatively and significantly correlated with economic growth in our sample economies. In other words, human capital increase will result in a decrease in GDP growth for these Latin American countries. The finding is consistent with Benhabib and Spiegel (1994), who advocate a negative impact of human capital on economic growth. This typical outcome may be due to the needlessness of western technical skills; nevertheless, it could also be because of the importance of the transfer of know-how and the successful spill over of technologies by the limited number of skilled people from investing countries rather than the dependence on mass human capital. Perhaps in some economies, the quality of human capital is greater than the quantity.

\section{Conclusion and Policy Implications}

This study investigated the association amongst FDI and economic growth of seven (7) Latin American countries with fixed effect panel estimation. The results indicate that lagged FDI has a positive and statistical significance impact on economic growth in Latin American countries.

The obtained results indicate a positive relationship between domestic investment and economic growth. Furthermore, trade openness having an optimist impact on economic development only makes sense as fewer barriers for trade enhance production in recipient countries and promote specialization amongst regions to trade their needs for win-win situations. Moreover on our analysis, the only negative and significant impact human capital has on economic growth is seen as a surprising result as many authors have stated that human capital is necessary for host countries' in order to benefit from capital inflows (Bengoa and Sanchez-Robles, 2003). Even though Kottaridi and Stengos, (2010) suggest human capital absorptive capacity is not necessarily important for growth but a more controversial subject since human capital seems to have a non-linear impact and found high income countries more significant compared to low-income economies considering economic growth.

In conclusion, following the seven (7) country panel analysis, we therefore suggest that Latin American governments must focus on upgrading their local labour force to improve upon their respective skills and fully rely on them for the countries' needed services while limiting FDI inflows in the form of human capital. The governments should not think of a complete avoidance since it could absolutely stop the inflows of the other forms of FDI. Nevertheless, one effectual method of pulling FDI into economies, considering its costs and weaknesses together with natural resource endowment for some regions could simply lie under practicing policies which would make recipient counties become attractive Foreign Direct Investment locations. 
Note: ${ }^{1}$ The sample countries include Brazil, Nicaragua, Mexico, Colombia, Chile, Peru and Argentina.

\section{References}

1. Adams S. (2009), 'Foreign Direct Investment, domestic investment, and economic growth in Sub-Saharan Africa,' Journal of Policy Modelling 31:939-949

2. Alfaro L. (2003),' Foreign direct investment and growth: Does the sector matter,' Harvard Business School Working Paper: 1-31

3. Alfaro L., Chanda A., Kalemli-Ozcan S. and Sayek S. (2004),' FDI and economic growth: the role of local financial markets,' Journal of International Economics, 64(1): 89-112.

4. Alfaro, L, and Maggie X. (2013),' Market Reallocation and Knowledge Spill over: The Gains from Multinational Production,' Harvard Business School Working Paper No. 12-111.

5. Alguacil M, Cuadros A, Orts V. (2011),'Inward FDI and growth: The role of macroeconomic and institutional environment,' Journal of Policy Modelling 33(3): 481-496.

6. Amin S. (1974),'Accumulation on a world Scale: A critique of the theory of understanding,' New York: Monthly Review Press.

7. Anyanwu, J. (2014),'Does Intra-African Trade Reduce Youth Unemployment In Africa?,' Working Paper Series NO 201. African Development Bank. Tunis. Tunisia.

8. Balasubramanyam N, Salisu $\mathrm{M}$ and Sapsford D. (1999),' Foreign direct investment as an engine of growth,' Journal of International Trade and economic Development (8) :pp 27-40

9. Bengoa-Calvo M, and Sanchez-Robles B. (2003),'Foreign Direct Investment, economic freedom and growth: new evidence from Latin America,' European Journal of Political Economy 19(3): 529-545.
10. Benhabib, Jess and Mark M. Spiegel. (1994),'The Role of Human Capital in Economic Development: Evidence from Aggregate Cross Country Data,' Journal of Monetary Economics, 34,143 pp. 173.

11. Blanco L. (2012),'The Spatial Interdependence of FDI in Latin America,' World Development 40(7): pp $1337-1351$

12. Borensztein E, De Gregorio J. and Lee J. (1998),'How does foreign direct investment affect economic growth?,'Journal of International Economics 45(1): pp 115-135

13. Bornschier V, Chase-Dunn C. (1985),'Transnational corporations and underdevelopment,' New York: Praeger.

14. Carkovic M, Levine R. (2005),'Does foreign investment accelerate economic growth? In T. H. Moran, E. M. Graham, and M. Blömstrom (Eds.), Does FDI promote development?' pp 195-220.Washington, D.C.: Institute for International Economics.

15. De Gregorio, J. (1992),'Economic growth in Latin American,' Journal of Development Economics, 39, 59- 83.

16. De Mello R. (1999),' Foreign Direct Investment-Led Growth: Evidence from Time Series and Panel Data,' Oxford Economic Paper 51, no 1: pp 133-151

17. Dutta, N and Roy, S. (2011),'Foreign Direct Investment, Financial Development and Political Risk,' Journal of Developing Areas 44(2): pp 303-327

18. Egan, Patrick J.W. (2010),'Hard bargains: The impact of multinational corporations on economic reform in Latin America,' Latin American Politics and Society 52, no 1: 1-32

19. Görg H, Greenaway D. (2004),'Much Ado about nothing? Do domestic firms really benefit from foreign direct investment?,' Word Bank Research Observer, 19(2): 171197

20. Kottaridi, $\mathrm{C}$ and Stengos, T. (2010),'Foreign direct investment, human capital and non-linearities in economic growth,' Journal of Macroeconomics 32(3): pp 858-871 
21. Lora, E .(2001),'Structural Reforms in Latin America: What Has Been Reformed and How to Measure it,' Inter-American development Bank, 348: pp.1-52

22. Mehic, E., Silajdzic, S. and Babic-Hodovic V. (2013),'The Impact of FDI on Economic Growth: Some Evidence from Southeast Europe,' Emerging Market Finance \& Trade. Vol 49. Supplement 1: pp 5-20

23. Muhammad, A., Muhammad, F., Muzaffar, A. and Muhammad, S. (2011),'Market size effect on foreign direct investment: A Case of Malaysia,' Interdisciplinary Journal of Contemporary Research in Business, 3(7), 1002-1007.

24. Naveed, A and Shabbir, G. (2006),'Trade Openness, FDI and Economic Growth A Panel Study,' Pakistan Economic and Social Review 44(1): pp 137-154

25. Neelankavil J., Stevans L. and Roman F. (2011),'Correlates of economic growth in developing countries: a panel cointegration approach,' International Review of Applied Economics 26(1): pp 83-96

26. Organisation for Economic co-operation and Development (OECD). (2008), Benchmark Definition of foreign Direct Investment: (4thed).
27. Quazi, R. (2007),'Economic freedom and foreign direct investment in East Asia,' Journal of the Asian Pacific Economy 12, no 4: $329-44$

28. Romer, P. (1986),'Increasing Returns and Long Run Growth,' Journal of Political Economy Vol 94. No 5. pp 1002-1037

29. Romer, P. (1990),'Endogenous Technological Change,' Journal of Political Economy 98 (5). S71-S102

30. Solow, R. (1956),'A Contribution to the Theory of Economic Growth,' The Quarterly Journal of Economics Vol 70. No 1. (Feb., 1956): pp 65-94

31. Xu, B. (2000),'Multinational Enterprises, Technology Diffusion, and Host Country Productivity Growth,' Journal of development Economics 62, 477-493.

32. Yusufu, K. (2013),'Foreign Direct Investment and Growth in Sub-Saharan Africa What are the Channels?,' Unpublished Philosophy Doctorate Proposal, University of Kansas. 